\title{
CIRCUMVENTING TITLE III: THE USE OF PEN REGISTER SURVEILLANCE IN LAW ENFORCEMENT
}

\section{INTRODUCTION}

Title III of the Omnibus Crime and Safe Streets Act of $1968^{1}$ was intended to be a comprehensive electronic surveillance statute. ${ }^{2}$ It prohibits all wiretapping and other electronic surveillance, unless conducted according to the Act's strict procedures (including judicial supervision) ${ }^{3}$ by law enforcement officials investigating certain specified crimes. ${ }^{4}$ The reasons for this legislative enactment of electronic surveillance controls are found in two contradictory societal goals: first, there is a pressing need for the increased use of electronic surveillance techniques in law enforcement, particularly in the investigation of suspected organized crime activities; ${ }^{5}$ and second, there is the equally important concern for eliminating unnecessary invasions of the privacy of innocent citizens which may result from the indiscriminate use of these techniques. ${ }^{6}$

Closer examination reveals that Title III is not a comprehensive treatment of the field of electronic surveillance. The scope of the Act is limited

THE FOLLOWING CITATIONS WILL BE USED IN THIS NOTE:

Application of the United States of America in the Matter of an Order Authorizing the Use of a Pen Register or Similar Mechanical Device, 538 F.2d 956 (2d Cir. 1976), cert. granted sub nom. United States v. New York Tel. Co., 429 U.S. 1072 (1977) [hereinafter cited as Application of the United States (Second Cir.)];

Application of the United States for an Order Authorizing Installation and Use of a Pen Register, 546 F.2d 243 (8th Cir. 1976) [hereinafter cited as Application of the United States (Eighth Cir.)];

Application of the United States of America for an Order Authorizing Use of a Pen Register Device, 407 F. Supp. 398 (W.D. Mo. 1976) [hereinafter cited as Application of the United States (D. Mo.)].

1. 18 U.S.C. $\S \S 2510-2520$ (1970). Act of June 19, 1968, Pub. L. No. 90-351, 82 Stat. 187, as amended by Act of January 2, 1971, Pub. L. No. 91-644, 84 Stat. 1891 (amending $\$ 2516$ ); Act of October 15, 1970, Pub. L. No. 91-452, 84 Stat. 930 (repealing $§ 2514$, amending $\$ \S 2516$ \& 2517); Act of July 29, 1970, Pub. L. No. 91-358, 84 Stat. 654 (amending \$§ 2511, 2518 \& 2520).

2. See, e.g., Gelbard v. United States, 408 U.S. 41, 46-52 (1972); United States v. United States Dist. Court, 407 U.S. 297, 301-05 (1972); Application of the United States (Second Cir.), 538 F.2d at 958.

3. See 18 U.S.C. $\$ \S 2516-2519$ (1970).

4. I8 U.S.C. $\S 2516$ (1970) lists the specific crimes which may be investigated by use of electronic surveillance.

5. See President's Commission on Law Enforcement and Administration of Justice, The Challenge of Crime in a Free Society 203 (1967).

6. Id. at 202; see also Advisory Committee on The Police Function, American Bar association, Standards Relating to Electronic Suryeillance 96 (1968). The Committee sets forth majority and minority views which, respectively, advocate expanding and limiting the use of electronic surveillance. The unanimous suggestion of both the majority and minority was that any use of electronic surveillance be only under explicit statutory control. 
to those interceptions achieved by means of an "aural acquisition of the contents of any wire or oral communication through the use of any electronic, mechanical, or other device." Under this definitional limitation, the extremely useful device known as the pen register is not covered by Title III. A succinct description of the function of a pen register was given by Justice Powell in his partial dissent in United States $v$. Giordano: ${ }^{8}$

A pen register is a mechanical device attached to a given telephone line and usually installed at a central telephone facility. It records on a paper tape all numbers dialed from that line. It does not identify the telephone numbers from which incoming calls originated, nor does it reveal whether any call, either incoming or outgoing, was completed. It does not involve any monitoring of telephone conversations. ${ }^{9}$

The courts have agreed that since the pen register does not "hear" sounds, there is no "aural acquisition," and, therefore, the device is not subject to Title III regulation and restriction. ${ }^{10}$ The legislative history of Title III confirms the intentional omission of the pen register from the scope of the Act:

The proposed legislation is not designed to prevent the tracing of phone calls. The use of the "pen register," for example would be permissible. But see U.S. v. Dote, 371 F.2d 176 (7th Cir. 1966). The proposed legislation is intended to protect the privacy of the communication itself and not the means of communication. ${ }^{11}$

7. 18 U.S.C. $\$ 2510(4)$ (1970) (emphasis added). 18 U.S.C. $\$ 2510(8)$ (1970) defines "contents" as "any information concerning the identity of the parties to such communication or the existence, substance, purport, or meaning of that communication." On the surface it would seem that the function of the pen register, the recordation of the numbers dialed from a specific telephone, would be covered by this definition. However, since the penalty provisions are written in terms of an "interception," a function not performed by a pen register, the device is not covered by Title III. This interpretation is supported by the legislative history of Title III. See note 11 infra and accompanying text.

8. 416 U.S. SOS (1974).

9. Id. at 549 n.1 (Powell, J., concurring in part and dissenting in part). For further descriptions of the pen register, see Southern Bell Tel. \& Tel. Co. v. United States, 541 F.2d 1151, 1152 n.2 (5th Cir. 1976); Application of the United States (Second Cir.), 538 F.2d at 957.

10. See United States v. Giordano, 416 U.S. S05, 553-54 (Powell, J., concurring in part and dissenting in part); Application of the United States (Eighth Cir.), 546 F.2d at 245; Application of the United States (Second Cir.), 538 F.2d at 958; United States v. Illinois Bell Tel. Co., 531 F.2d 809, 811 (7th Cir. 1976); United States v. Clegg, 509 F.2d 605, 610 (5th Cir. 1975); United States v. Falcone, 505 F.2d 478, 482 (3d Cir. 1974), cert. denied 420 U.S. 955 (1975); United States v. Finn, 502 F.2d 938, 942 (7th Cir. 1974); United States v. Brick, 502 F.2d 219, 223 (8th Cir. 1974).

11. S. Rep. No. 1097, 90th Cong., 2d Sess. 90 (1968). The quoted portion of the Senate Report is the source of what one might call the "but see Dote" controversy. Both the telephone company and the government rely on this citation to defend their positions. The Brief for Appellant at 18, Application of the United States (Second Cir.), gives a concise description of the facts of Dote and the telephone company's interpretation of the reference in the legislative history of Title III:

In Dote, a telephone company informed the Internal Revenue Service that it suspected a certain telephone was being used for bookmaking and, at the request of 
While it is thus clear that the pen register is not subject to Title III, it is not clear what use may be made of it by the government, and under what restrictions. ${ }^{12}$ This uncertainty has contributed to a growing controversy between law enforcement agencies and telephone companies over the use of the pen register. ${ }^{13}$ The government contends that the pen register is a vital law enforcement tool, ${ }^{14}$ and that in most instances a court order authorizing

the IRS, installed a pen register. The company turned over to the IRS the results of the pen register without having been served with a subpoena or other judicial process. The court held that while pen registers serve an important function in telephone company internal operations, and, therefore, their use was permissible, the release of the pen register results in that case without a subpoena was a violation of $\S 605$ of the Communications Act (47 U.S.C $\$ 605$ ). Thus, the statement in the legislative history that a pen register would be permissible, with the warning that the holding of Dote should be noted, may well indicate that Congress was aware telephone companies used pen registers in the ordinary course of business, and a recognition that they could continue to do so as long as they did not become an arm of law enforcement outside the provisions of Title III, as in the Dote case.

The government argues that since the pen register is not covered by Title III, its use is constrained only by the fourth amendment. See note 12 infra and accompanying text. According to the government, the cite to Dote meant only that the usage must be on demand of lawful authority in order to come within the exception in 47 U.S.C. $\$ 605$ (1970), as amended by Title III in 1968:

[N]o person receiving, assisting in receiving, transmitting, or assisting in transmitting, any interstate or foreign communication by wire or radio shall divulge or publish the existence, contents . . . except ... (6) on demand of other lawful authority.

One commentator has gone so far as to say that the citation was "an example of a legislative reporting practice used throughout the Senate Report to indicate the cases [which] are no longer controlling." Note, The Legal Constraints Upon the Use of the Pen Register as a Law Enforcement Tool, 60 CORNELL L. REv. 1028, 1035 n.44 (1975). As recognized by the Government, however, $\S 605$ as amended still has validity as a penalty provision for the unauthorized interception of communications; judicial decisions subsequent to Title III's passage appear to give Dote some residual validity. See United States v. Lanza, 341 F. Supp. 405, 422 (M.D. Fla. 1972) (pen register orders fall within Title III when they are issued in conjunction with a wiretap, but when no wiretap is involved, pen registers are still governed by $\S 605$ as interpreted in Dote). The telephone company's interpretation of the legislative history, which would allow the use of the pen register only by a telephone company in the regular course of business, would maintain the integrity of the stringent requirements of Title III, since the pen register, if used only after a showing of probable cause, would allow the government to gain the information necessary to receive Title III wiretap authorization in a manner which circumvents the requirements of the Act.

I2. It is clear, after Katz v. United States, 389 U.S. 347 (I967), that the pen register is subject to the fourth amendment's "probable cause" requirements. See United States v. Giordano, 416 U.S. 505, 553-54 (Powell, J., concurring and dissenting); Application of the United States (Eighth Cir.), 546 F.2d at 245; id. at 247 (Lay, J., dissenting); Application of the United States (Second Cir.), 538 F.2d at 959-60; id. at 963 (Mansfield, J., concurring and dissenting); United States v. Illinois Bell Tel. Co., 531 F.2d 809, 813 (7th Cir. 1976). The government readily concedes that the pen register is subject to the fourth amendment: "Use of pen register device is conditioned upon respect for the probable cause requirements of the fourth amendment." Brief for Appellee at 1, United States v. Illinois Bell Tel. Co., 531 F.2d 809 (7th Cir. 1976). See also Application of the United States (Second Cir.), 538 F.2d at 959; Application of the United States (D. Mo.), 407 F. Supp. at 401.

13. For a full discussion of the arguments of the government and the telephone company, see notes 52-66 infra and accompanying text.

14. It is readily admitted that without the evidence derived through the use of the pen 
the use of a pen register cannot be implemented without telephone companies providing information, facilities and technical assistance. ${ }^{15}$ The companies are no longer willing to provide such assistance:

A.T. \& T. [American Telephone and Telegraph] has apparently recommended to all Bell Telephone subsidiaries that company participation in a pen register device installation is forbidden as a matter of company policy unless such installation will have been authorized pursuant to "the safeguards of the federal wiretap statutes . . . ."16

The rationale behind this company policy is a concern for potential civil or criminal liability, ${ }^{17}$ as well as the need to protect the integrity of the telephone as a communications medium. ${ }^{18}$ This controversy has lead to litigation by various Bell subsidiaries seeking to resist governmental use of the pen register. The two basic issues are: (1) whether the courts have the power to authorize governmental use of the pen register; and (2) assuming such power exists, whether the courts have the power to compel the telephone company to assist in its installation. ${ }^{19}$

The resolution of these issues depends in large measure upon the proper view of the power of the courts in our federal scheme. Since Congress has not authorized the investigative use of the pen register, any judicial power to authorize its use must be found in the vague and nebulous concept of "inherent judicial power." A court, performing its judicial function of deciding "cases and controversies," 20 has considerable inherent power to issue whatever orders are necessary to effectuate its jurisdiction and judgment. Where, however, the judicial branch is requested to authorize executive investigations, there is no constitutional justification for such action without express statutory authorization by Congress, since such investigative authorization is hardly indispensible to the discharge of any judicial duty. ${ }^{21}$ Accordingly, it is contended in this Note that, absent congressional authorization, the federal courts lack the power to authorize the use of the pen register by the government. Secondly, even if the courts reject this limitation and find it within their inherent power to authorize the use of the

register, government agents, in many cases, could not satisfy the probable cause requirements of Title III in order to obtain judicial authorization for a wiretap. Conversation with Edward Jennings, United States Attorney, Greensboro, North Carolina (Nov. 23, 1976).

15. Application of the United States (Eighth Cir.), 546 F.2d at 246; Application of the United States (Second Cir.), 538 F.2d at 957-58.

16. Application of the United States (D. Mo.), 407 F. Supp. at 399 n.1.

17. Reply Brief for Appellant at 6, United States v. Illinois Bell Tel. Co., 531 F.2d 809 (7th Cir. 1976). See note 63 infra and accompanying text.

18. Brief for Appellant at 9, Application of the United States (Second Cir.).

19. A subsidiary aspect of this second issue is whether the courts should exercise this power even if they have it.

20. U.S. ConST. art. 11I.

21. Any investigative activities would be in the executive realm prior to the involvement of the courts in trying the eventual defendant. 
pen register, they should not exercise the concomitant power to compel private assistance in the installation of the device.

\section{JUDICIAL POWER TO AUTHORIZE THE USE OF THE PEN REGISTER}

Since the passage of Title III, the question of whether law enforcement agencies may use the pen register, and with what safeguards, has been unsettled. ${ }^{22}$ With one recent exception, ${ }^{23}$ the courts have granted government requests for authorization to use the pen register. ${ }^{24}$ However, few of these courts have carefully analyzed the issue; the courts' power to authorize the government's use of a pen register has often been either assumed without discussion, ${ }^{25}$ or, tied to dicta in Justice Powell's separate opinion in United

22. An initial problem is whether $\S 605$ of the Federal Communications Act of 1934,47 U.S.C. $\S 605$ (1970), is applicable to the use of the pen register. Although section 605 was amended by Title III in 1968 in such a way that interceptions outside of the coverage of Title III may still be subject to penalty under the revised $\S 605$, see note 11 supra, the legislative history of Title III itself leaves some doubt as to whether $\$ 605$ should be applied at all in the context of wire and oral communications:

This [new] section amends section 605 of the Communications Act of $1934 \ldots$. .

This section is intended as a substitute. The regulation of the interception of wire or oral communications in the future is to be governed by [Title III].

S. REP. No. 1097, supra note 11, at 107 (emphasis added).

23. Application of United States (D. Mo.), discussed in notes 28-36 infra and accompanying text.

24. Those cases which have allowed the use of the pen register after the enactment of Title $11 \mathrm{I}$ are (cases where there was an accompanying Title III wiretap are marked with an ${ }^{*}$ ): United States v. Giordano, 416 U.S. 505 (1974); Application of the United States (Eighth Cir.); Application of the United States (Second Cir.); United States v. Illinois Bell Tel. Co., 531 F.2d 809 (7th Cir. 1976); United States v. Clegg, 509 F.2d 605 (5th Cir. 1975); United States v. John, 508 F.2d 605 (5th Cir. 1975); In re Joyce, 506 F.2d 373 (5th Cir. 1975); United States v. Shaefer, 510 F.2d 1307 (8th Cir. 1974), cert. denied sub nom. Del Pietro v. United States, 421 U.S. 975 (1975); United States v. Falcone, 505 F.2d 478 (3d Cir. 1974), cert. denied, 420 U.S. 955 (1975); United States v. Brick, 502 F.2d 219 (8th Cir. 1974); United States v. Finn, 502 F.2d 938 (7th Cir. 1974); Korman v. United States, 486 F.2d 926 (7th Cir. 1973); United States v. DeLeeuw, 368 F. Supp. 426 (E.D. Wis. 1974); United States v. Best, 363 F. Supp. 11 (S.D. Ga. 1973); *In re Alperen, 355 F. Supp. 372 (D. Mass.), aff'd sub nom. United States v. Doe, 478 F.2d 194 (1973); United States v. Lanza, 341 F. Supp. 405 (M.D. Fla. 1972); United States v. King, 335 F. Supp. 523 (S.D. Cal. 1971); aff'd in part, rev'd in part, 478 F.2d 494 (9th Cir.), cert. denied sub nom. Light v. United States, 414 U.S. 846 (1973); United States v. Escandar, 319 F. Supp. 295 (S.D. Fla. 1970); United States v. Vega, 52 F.R.D. 503 (E.D.N.Y. 1971). The courts have unanimously upheld the use of a pen register when employed in combination with a wiretap which has been authorized by the court under the stringent procedures of Title III.

25. The cases have either assumed that the court could authorize the use of the pen register because it was also authorizing a Title III wiretap, see cases cited in note 24 supra, or, where the pen register was not accompanied by a Title III wiretap, the courts have ignored the issue of their power to authorize its use, emphasizing instead the fact that issuance was based on probable cause. See, e.g., United States v. Focarile, 340 F. Supp. 1033, 1041 (W.D.Md.), aff'd sub nom. United States v. Giordano, 469 F.2d 522 (3d Cir. 1972), aff'd, 416 U.S. 505 (1974) (rejecting a motion to suppress the fruit of a pen register, observing that it was properly issued pursuant to Rule 41 upon a showing of probable cause); United States v. Best, 363 F. Supp. 11 (S.D. Ga. 1973) (order supported by probable cause so no need to suppress evidence derived 
States v. Giordano: ${ }^{26}$ "Because a pen register device is not subject to the provisions of Title III, the permissibility of its use by law enforcement authorities depends entirely on compliance with the constitutional requirements of the Fourth Amendment." 27 Only the recent Eighth, Second and Seventh Circuit opinions, discussed in Section III of this Note, have explained the bases of their decisions. They have found the authority in their "inherent power," as well as from analogy to Rule 41 of the Federal Rules of Criminal Procedure, which governs the search and seizure of tangible property.

One recent district court case held that the court did not have jurisdiction to authorize the use of a pen register. In Application of United States of America for an Order Authorizing Use of a Pen Register Device ${ }^{28}$ the government, applying to the district court for authorization to use a pen register, "conceded" that there was no "specific statutory authority or rule upon which its requested orders [could] be based." 30 The court refused the government's request to find support for such "a novel assertion of power" ${ }^{31}$ in the All Writs Act. ${ }^{32}$ The court noted that it was settled law that the All Writs Act does not create any jurisdiction in the courts, but only empowers them to issue writs in aid of jurisdiction already acquired on some independent basis. ${ }^{33}$ Since the district court felt that it did not have any independent jurisdiction over the investigation, it therefore was not given the power to issue the requested order by the All Writs Act. ${ }^{34}$ The court noted that "[q]uestions of power and jurisdiction must be determined on the basis of congressional action which has or has not been taken in regard to the subject matter of the particular question under consideration." 35 Since the "congressional action" in the area of electronic surveillance, Title II, was

from a pen register); United States v. Escandar, 319 F. Supp. 295 (S.D. Fla. 1970) (since Title III's requirements were satisfied, pen register use was proper, implying necessity of showing probable cause).

26. See Application of the United States (Eighth Cir.), 546 F.2d at 245; Application of the United States (Second Cir.), 538 F.2d at 959; United States v. Illinois Bell Tel. Co., 531 F.2d 809, 812 (7th Cir. 1976); United States v. John, 508 F.2d 1134 (8th Cir. 1975).

27. 416 U.S. at 553-54 (Powell, J., dissenting).

28. 407 F. Supp. 398 (W.D. Mo. 1976).

29. The government also sought an order "authorizing" the telephone company to assist the government. Id. at 399 . It was not necessary for the court to discuss this request, since it held that it did not have the power to authorize the government to use a pen register. Id. at 410 .

30. Id. at 402; see also id. at 400 .

31. Id. at 404.

32. 28 U.S.C. $\S 1651$ (a) (1970): "The [federal courts] may issue all writs necessary or appropriate in aid of their respective jurisdictions and agreeable to the usages and principles of law."

33. 407 F. Supp. at 405.

34. Id.

35. Id. at 403 . The application before the court was not a Title III application-it did not seek a wiretap in addition to the pen register, and the cases under investigation were outside of Title III's coverage. Id. 
meant to be comprehensive and all inclusive, the court concluded that an order authorizing the use of a pen register could be obtained only by following Title III's procedures, and, apparently, only in conjunction with a wiretap application. ${ }^{36}$

The approach taken by the court-that its jurisdiction and power are dependent on congressional action and cannot be based on any "inherent" judicial power-correctly states the role of the judiciary in our constitutional scheme. As Professor William Van Alstyne has recently pointed out, ${ }^{37}$ reliance on the necessary and proper clause ${ }^{38}$ as the source of implied executive or judicial powers is not constitutionally justified. The application of this interpretation to the present situation results in the conclusion that the courts may not approve applications for executive use of the pen register without congressional authorization.

Article III of the Constitution establishes the "judicial power of the United States," and enumerates the "cases" and "controversies" to which such power extends. Logically, then, the federal courts must have those powers which are indispensable to the trying of cases-for example, subpoena and contempt powers. This does not mean, however, that the courts have inherent powers that might be incidental, convenient, appropriate or helpful to the performance of their constitutional duties. This is true because Congress is constitutionally granted the exclusive legislative power in our federal scheme. More specifically, the necessary and proper clause leaves it to Congress to pass all laws necessary and proper (appropriate, convenient, helpful, etc.) for carrying into execution the express powers granted the governmental departments of the United States under the Constitution. However, if the courts, rather than Congress, determine for themselves and employ various incidental powers which are not indispensable to the exercise of their Article III duties, then one must interpret the necessary and proper clause so as to allow each department to delineate for itself the extent of its ancillary power. This latter interpretation is the source of the sprawling, amorphous concept of "inherent power" which some courts have used to support their authorization of executive use of the pen register.

A literal reading of the necessary and proper clause would constrain the courts to operate only within the framework of congressional authorization, unless the use of the pen register was considered indispensable to the

36. Id.

37. See Van Alstyne, The Role of Congress in Determining Incidental Powers of the President and of the Federal Courts: A Comment on the Horizontal Effect of the "Sweeping Clause," 36 OHIo Sr. L.J. 788 (1975).

38. "The Congress shall have the power . . . to make all Laws which shall be necessary and proper for carrying into Execution . . . all . . . Powers vested by this Constitution in the Government of the United States, or in any Department or Officer thereof." U.S. CoNST. art. $1, \S 8, \mathrm{cl} .18$ (emphasis added). 
trying of cases. ${ }^{39}$ At the stage of an investigation by the executive, there is no case or controversy involved, so the judiciary is unable to participate unless appropriately instructed by Congress. In the context of investigation in general, Congress has enacted the provisions of Rule 41 of the Federal Rules of Criminal Procedure, whereby the courts may authorize and direct a civil officer of the United States to search for and seize tangible objects as particularly described by an affidavit indicating probable cause to believe such objects exist and are properly the subject of a search. ${ }^{40} \mathrm{~A}$ simple reason for the inapplicability of Rule 41 to the seizure committed by the pen register is that the pen register seizes intangibles. ${ }^{41}$ The Eighth, Second and Seventh Circuits were willing to find the power to authorize the use of the pen register to seize intangibles by analogy to the seizure of tangibles under Rule $41 .{ }^{42}$ This analogy seems to be a reasonable one. ${ }^{43}$ The point is, however, that it is not for the courts to make such an analogy; Congress alone possesses the power to authorize action that is not indispensable to the exercise of the judiciary's express duties.

More specifically, in the context of electronic surveillance, Congress has spoken at length in the form of Title III, deliberately balancing the

39.Even as to questions that were the staple of judicial business, it is not for the courts to pass on them unless they are indispensably involved in a conventional litigationand then, only to the extent that they are so involved. Rigorous adherence to the narrow scope of the judicial function is especially demanded in controversies that arouse appeals to the Constitution.

Youngstown Sheet \& Tube Co. v. Sawyer, 343 U.S. 579, 594 (1952) (Frankfurter, J., concurring).

40. FED. R. CRIM. P. 41 provides in relevant part:

(c) Issuance and Contents ..... If the federal magistrate or state judge is satisfied that grounds for the application exist or that there is probable cause to believe that they exist, he shall issue a warrant identifying the property and naming or describing the person or place to be searched.

(h) Scope and Definition . . . . The term "property" is used in this rule to include documents, books, papers, and any other tangible objects. (emphasis added).

41. Brief for Appellant at 13-15, Application of the United States (Second Cir.).

42. Application of the United States (Eighth Cir.), 546 F.2d at 245 (majority opinion); Application of the United States (Second Cir.), 538 F.2d at 959; United States v. Illinois Bell Tel. Co., 531 F.2d 809, 813 (7th Cir. 1976).

43. Rule 41 was promulgated before the decisions in Berger v. United States, 388 U.S. 41 (1967), and Katz v. United States, 389 U.S. 347 (1967), which extended fourth amendment protection to intangible information seized by electronic surveillance. Prior to these landmark cases, it would have been unnecessary for Rule 41 to authorize the court to allow the government to seize intangibles, since the seizure of conversations without physical intrusion was considered to be outside the scope of fourth amendment protection. See, e.g., Silverman v. United States, 365 U.S. 505 (1961); Olmstead v. United States, 277 U.S. 438 (1928). Amendments to Rule 41 have been promulgated by the Supreme Court and approved by Congress frequently in recent years. See Federal Rules of Criminal Procedure Amendments Act of 1975 , Pub. L. No. 94-149, 89 Stat. 805 (Dec. 12, 1975). However, rule 41(h), which limits courtauthorized seizures to tangibles, has not been changed by Congress. 
conflicting needs of our society for both security and privacy. ${ }^{44}$ Congress deliberately left this device outside the coverage of Title III, perhaps unaware of its full wiretap capabilities. ${ }^{45}$ Quite possibly, its intention, as the telephone companies contend, was to permit the pen register to be used only by the companies for business purposes. ${ }^{46}$ The legislative history, however, does not clearly evidence Congress' intent. Given the comprehensiveness of Title III, though, it seems appropriate to leave to Congress any decisions extending the investigative use of electronic surveillance techniques. Therefore, finding a judicial power to authorize the use of such a potentially abusive device as the pen register does more than just usurp unexercised congressional prerogative; the effect is to allow a direct circumvention of the legislatively expressed policy-namely, the control of any use of electronic surveillance, including that by federal agents.

There may be, however, "an anticlimactic conclusion" to this interpretation of the necessary and proper clause, for there is a series of interpretive rationales through which the power of the courts to authorize the use of the pen register can be asserted. ${ }^{47}$ To give just two examples, the courts might find congressional authorization in Rule 41 as judicially "updated" to keep abreast of technology; or, the courts might interpret the fourth amendment warrant clause as an express constitutional basis for interjecting the judiciary into the investigative domain. But the opinion of the Missouri District Court in Application of United States ${ }^{48}$ and the dissent to the Eighth Circuit's opinion in Application of the United States for an Order Authorizing Installation and Use of a Pen Register ${ }^{49}$ show that there need not be "an anticlimactic conclusion." Hopefully, other courts will follow these examples and refuse to authorize the use of the pen register until Congress does the necessary legislating.

44. See notes $5 \& 6$ supra.

45. See Brief for Appellant at 10, United States v. Illinois Bell Tel. Co., 531 F.2d 809 (7th Cir. 1976). The telephone company pointed out the potential of the pen register:

For practical purposes, however, one need only plug a headset into the pen register and all conversation can be overheard. In some of the newer models, a tape recorder plugs into the pen register and an automatic voice actuated switch will automatically turn the tape recorder on and off as the telephone is used.

The courts are not unaware of this danger. The Fifth Circuit observed: "Notwithstanding the apparent sterility of a pen register . . . , expert testimony has indicated that once a pen register has been installed, a full wiretap 'interception' of telephone conversations may be accomplished simply by attaching headphones or a tape recorder to the appropriate terminal on the pen register unit." In re Joyce, 506 F.2d 373, 377 n.4 (5th Cir. 1975).

46. See note 11 supra and accompanying text. The telephone company uses the pen register to check the integrity of their billing procedures, to apprehend suspected nuisance callers, to detect evasion of long distance charges and for other business purposes. See generally Claerbout, The Pen Register, 20 DRAKE L. REv. 108, 110-11 (1970).

47. See Van Alstyne, supra note 37 , at 819-25.

48. Application of the United States (D. Mo.).

49. Application of the United States (Eighth Cir.), 546 F.2d at 247. 


\section{The Power to Compel Telephone Company Assistance IN THE INSTALLATION OF A PEN REGISTER}

If the courts follow the position adopted by the Missouri District Court in Application of United States - that the courts may not authorize executive use of the pen register-then the inquiry need go no further. However, where a court rejects this view and holds that it does have the power to authorize the government's use of the pen register, then a second problem frequently arises-whether the court has the further power to compel the telephone company, a third party, to assist the government in the installation of the device. Of course, if the telephone company voluntarily assists the government, this problem need not be addressed by the courts. But since telephone companies now seem opposed to the use of the pen register, ${ }^{50}$ this question appears destined for more frequent litigation. So far the Eighth, Second and Seventh Circuits have been faced with this question, and have reached different conclusions. ${ }^{51}$ In order to understand these decisions, it is helpful to briefly examine the arguments of the government and the telephone companies.

\section{A. The Government's and Telephone Companies' Positions}

The government's position can best be described as that of beleaguered law enforcement agencies forced to employ extraordinary techniques such

50. See note 16 supra and accompanying text.

51. The issue was also raised in the Fifth Cireuit in Southern Bell Tel. \& Tel. Co. v. United States, 541 F.2d 1151 (5th Cir. 1976). In that case, the district court ordered the telephone company to assist government agents in the installation of a pen register. The telephone company sought a stay of the order, but the stay was denied by the Fifth Circuit. Id. at \$152. The telephone company therefore complied with the order to avoid contempt charges, but also appealed to the Fifth Circuit; that court dismissed the case as moot, since the telephone company had complied with the orders which had since expired. The court, however, noted the seriousness of the issue, stating: "The law cannot ignore indefinitely the plight of a party in Southern Bell's precarious situation-damned by potential civil liability if it does comply with the Distriet Court's order and damned by a possible contempt citation if it does not." Id. at 1156. The court suggested that the next time the issue arose, the district court should "seriously consider a stay to permit review," and all but promised an expedited emergency appeal.

The issue has also arisen in the related context of whether a court can compel the telephone company to assist in the "trapping and tracing" of a telephone call; this question is currently being litigated before the Sixth Circuit by the Justice Department's Strike Force, and at the state level in New Jersey. See In the Matter of an In-Progress Trace, 138 N.J. Super. 404, 351 A.2d 356 (1975), cert. granted, 70 N.J. 144, 358 A.2d 191 (1976). The lower court "thought" it could compel telephone company assistance in tracing, a function outside the provision of New Jersey's writ of authorization law, by court order "similar to a search warrant" or grand jury subpoena. Briefly, tracing "locates an unknown telephone from which a known one is being called, and records the fact that the call is being made but does not hear it." 138 N.J. Super. at 412,351 A.2d at 361 . That is, it is the converse of a pen register-the pen register records the telephone numbers dialed from the target telephone, while a "trace" records the telephone numbers which are calling to the target telephone. For a more complete description of tracing, see State v. Hibbs, 123 N.J. Super. 152, 301 A.2d 739 (1972). 
as electronic surveillance in order to combat increasingly sophisticated lawbreakers. ${ }^{52}$ Accordingly, any limitation on the government's ability to employ these techniques is seen as an unwarranted and unjustifiable road block to "law and order." 53 The pen register has proven invaluable to federal agents; the information derived from its use often supplies the "probable cause" needed to enable the government to apply for permission to wiretap substantive communications under the very strict procedures and requirements of Title $\mathrm{III} .{ }^{54}$ Not surprisingly, the government has not chosen to request that Congress bring the device within the coverage of Title III, ${ }^{55}$ opting instead to rely on judicial authorization. ${ }^{56}$ Certainly such an approach is in the government's interest, since it avoids the procedural difficulties of Title III. ${ }^{57}$ As to compelling telephone companies' assistance, the government points out that the court should not allow a "monopolistic communications carrier"' to frustrate the effect of the order authorizing the use of the pen register, since that order would be worthless without technical assistance from the telephone company. ${ }^{58}$ The government questions telephone company motivation by emphasizing that there is no major time or effort involved in providing assistance, and the company would be compensated for its services. ${ }^{59}$ Furthermore, the government believes that the telephone companies' fears of potential civil or criminal liability are groundless. ${ }^{60}$ Because assistance would be provided under "order of lawful authority," the telephone company would be protected by the "immunity" provisions of Title III or Section $605 .{ }^{61}$

The telephone companies are concerned about the invasion of the privacy of those whose telephone calls are monitored by pen register

52. See note 5 supra and accompanying text.

53. Brief for Appellee at 11-12, United States v. Illinois Bell Tel. Co., 531 F.2d 809 (7th Cir. 1976).

54. See note 14 supra and accompanying text.

55. Reply Brief for Appellant at 7, United States v. Illinois Bell Tel. Co., 531 F.2d 809 (7th Cir. 1976).

56. Conversation with James P. Walsh, Special Attorney, Chicago Strike Force, Department of Justice (Nov. 8, 1976).

57. An additioual reason is that there is no guarantee that Congress would authorize compulsion of telephone company assistance as it did when the problem of forced private assistance arose under Title III. See notes 107-10 infra and accompanying text; Application of the United States (Second Cir.), 538 F.2d at 962. One government attorney admitted to a fear of the "basic hostility to the idea of interceptions held by Congress." Conversation with James P. Walsh, Special Attorney, Chicago Strike Force, Department of Justice (Nov. 8, 1976).

58. Brief for Appellee at 11, United States v. Illinois Bell Tel. Co., 531 F.2d 809 (7th Cir. 1976).

59. Application of the United States (Second Cir.), 538 F.2d at 962.

60. Brief for Appellee at 18-21, United States v. Illinois Bell Tel. Co., 531 F.2d 809 (7th Cir. 1976).

61. 18 U.S.C. $\$ 1510$ (1970) (Title III immunity provision for good faith reliance on a court order); 47 U.S.C. $\$ 605(6)$ (1970) (exception to the penalty for unauthorized interception of wire or oral communication for interceptions made on "demand of other lawful authority"). 
surveillance, ${ }^{62}$ and the invasion of their own privacy. They also fear criminal or civil liability ${ }^{63}$ The companies' statutory arguments center around the comprehensive scope of TitIe III, and the fact that Congress found it necessary to amend that Act to provide express authority allowing a court to order private assistance in the installation of wiretaps. ${ }^{64}$ In addition, they argue that the legislative history of Title III, explicitly recognizing lawful utilization of the pen register, indicated Congressional intent that the device be exempt from the provisions of the Act only when employed by the telephone company in the ordinary course of its business. ${ }^{65}$ Finally, the companies, fearing that this could be the "first step down a long road," remind the court exactly what is at stake by offering a striking analogy:

The court's power is not limitless. The government would be hard pressed to justify an order on an independent accountant to analyze a set of books to unearth a criminal scheme if the accountant chose not to do so. Similarly, the court could not properly order an individual scientist to analyze a chemical substance or formula for criminality nor could the court order a firm to run a computer study for the government prosecutor. ${ }^{66}$

\section{B. The Courts' Views}

The power of the courts to compel the telephone companies to assist the government in the installation of a pen register was first faced by the

62. A statement made to the National Commission for the Review of the Wiretap Laws by Attorney General Saxbe highlights current public sentiment:

We see now a spreading concern among large sectors of the public that they or their

families may be the subject of wiretapping or bugging. Decent, law abiding people

feel a moment of uneasiness, if not a tinge of fear, when they hear quick or suspicious background noises on their telephones.

Quoted in Brief for Amicus Curiae American Civil Liberties Union of New Jersey at 19, In the Matter of an In-Progress Trace, No. 12, 269 (Supreme Court of New Jersey, filed October 4, 1976).

63. 47 U.S.C. $\$ 605$ (1970) provides in relevant part:

Except as authorized by Chapter 119, Title 18, no person receiving, assisting in receiving, transmitting, or assisting in transmitting, any interstate or foreign communication by wire or radio shall divulge or publish the existence, contents, substance, purport, effect, or meaning thereof, except through authorized channels of transmission or reception, (1) to any person other than the addressee, his agent, or attorney, (2) to a person employed or authorized to forward such communication to its destination, (3) to proper accounting or distributing officers of the various communicating centers over which the communication may be passed, (4) to the master of a ship under whom he is serving, (5) in response to a subpoena issued by a court of competent jurisdiction, or (6) on demand of other lawful authority.

In addition, the telephone companies express fears of liability under various other federal and state provisions such as 42 U.S.C. $\S 1983$ (1970), and state constitutional and statutory provisions (such as Ill. ConST. art. I, \$6(1970), and ILl. REv. STAT. ch. 38, \$14-1). See Reply Brief for Appellant at 6-7, United States v. Illinois Bell Tel. Co., 531 F.2d 809 (7th Cir. 1976). But see note 61 supra and accompanying text.

64. Brief for Appellant at 5, Application of the United States (Second Cir.).

65. Id. at 17. See note 11 supra.

66. Reply Brief for Appellant at 2, United States v. Illinois Bell Tel. Co., 531 F.2d 809 (7th Cir. 1976). 
Seventh Circuit in United States v. Illinois Bell Telephone $\mathrm{Co}^{67}$ In that case the district court found probable cause to believe that evidence of the commission of certain crimes $^{68}$ would be obtained by attaching a pen register to a particular telephone. It authorized government agents to install such a device on the telephone for thirty days. In addition, the district court's order required that Illinois Bell:

furnish the applicant forthwith all facilities, including leased lines, information, including the identification of leased line pairs, subscriber pairs and the location of a suitable junction box where connection can occur, and technical assistance necessary to accomplish the interception unobtrusively and with a minimum of interference with the services that such carrier is providing . . . ${ }^{69}$

The telephone company moved to vacate the district court's order, noting the inapplicability of Title III and its "private assistance" provisions ${ }^{70}$ and the lack of any other jurisdictional basis for the order. It expressed fear of possible criminal penalties and civil liability. ${ }^{71}$ The district court denied the motion to vacate and Illinois Bell appealed to the Seventh Circuit. While the telephone company did not dispute the power of the court to authorize the use of the pen register by federal agents, ${ }^{72}$ it contended that the court was without power to compel its unwilling assistance.

The Seventh Circuit rejected the telephone company's arguments and upheld the district court order. The Seventh Circuit opinion, however, was something of a "bootstrap" affair, aided unintentionally by the telephone company. Since the telephone company conceded the district court's power to authorize the government's use of the pen register, the court was able to gloss over that question with a passing reference to Justice Powell's statement in Giordano and its interpretation of Rule $41 .^{73}$ Because the district court's jurisdiction to issue the first order was not challenged, the Seventh Circuit found that the district court had the power to issue the supplemental order requiring the telephone company's assistance, either as an inherent judicial power or under the general congressional authority of the All Writs Act; otherwise the original order could be "frustrated and actually nullified by the caprice of a monopolistic communications carrier."74 The court

67. 531 F.2d 809 (7th Cir. 1976).

68. The alleged violations were of 26 U.S.C. $\$ 7262$ (1970) (failure to register as a person receiving wagers), neither of which are included in 18 U.S.C. $\$ 2516(1)$ (1970), Title III's list of crimes for which wiretaps may be authorized.

69. Brief for Appellant at 4, United States v. Illinois Bell Tel. Co., 531 F.2d 809 (7th Cir. 1976). See also 531 F.2d at 811.

70. Brief for Appellant at 4.

71. Id.

72. Id. at 6. See also $531 \mathrm{~F} .2 \mathrm{~d}$ at 811 .

73. 531 F.2d at 812-13.

74. Id. at 814 . 
rejected the company's analogy to the congressional enactment of an amendment to Title III expressly providing the judiciary with the power to compel assistance and indemnifying those providing such assistance from the penalty provision of Title III or any other law. Rather, the Seventh Circuit viewed the amendment as a confirmation of the inherent power already possessed by the courts to issue such supplemental orders; Congress was simply overruling the judicial view that Congress did not intend the courts to have this power. ${ }^{75}$

When the controversy arose in the Second Circuit in Application of the United States of America in the Matter of an Order Authorizing the Use of a Pen Register or Similar Mechanical Device, ${ }^{76}$ New York Telephone Company challenged both the district court's power to authorize the use of the pen register and the additional order compelling telephone company installation assistance. ${ }^{77}$ The Second Circuit panel unanimously held that the district court had the power to authorize the use of the pen register, ${ }^{78}$ agreeing with the reasoning of the Seventh Circuit's "commonsense approach" in United States v. Illinois Bell Telephone Co. ${ }^{79}$ The court's reasoning that "there exists a power akin to that lodged in Rule 41 to order the seizure of non-tangible property," $" 80$ is a clear example of the use of inherent power. As had the Seventh Circuit, the Second Circuit also placed great reliance on Mr. Justice Powell's suggestion that pen register use was subject only to fourth amendment restrictions.

The panel split, however, on whether the lower court could properly order the telephone company to provide technical assistance to the federal agents. In the majority opinion, the court assumed arguendo "that a district court has inherent discretionary authority or discretionary power under the All Writs Act to compel technical assistance by the Telephone Company." 81 The government's victory, however, was short-lived. The Seventh Circuit had found such power to exist, and it stopped its inquiry. The Second Circuit, however, went on to consider the possible reasons not to order such assistance. It emphasized that the "very general All Writs Act or the even more amorphous notion of inherent judicial power" 82 are not mandatory but

75. Id. at 813-14. The case referred to is the Ninth Circuit's decision in Application of the United States, 427 F.2d 639 (9th Cir. 1970); see notes 107-10 infra and accompanying text.

76. 538 F.2d 956 (2d Cir. 1976).

77. The telephone company offered a compromise solution-it agreed to provide information such as terminal locations and cable and pair identifications, so that the government could install the pen register, but it refused to provide telephone lease or private lines, citing telephone company regulations prohibiting such assistance. The government refused this offer believing that such lines were crucial for the installation of the pen register. Id. at 957-58.

78. Id. at 960 .

79. 531 F.2d at 813.

80. 538 F.2d at 959 (emphasis added).

81. Id. at 961 .

82. Id. at 962 (emphasis added). 
rather are "addressed to the discretionary power of the court."83 Following this characterization, the majority held that to order such private assistance would automatically be an abuse of discretion, absent specific and limited congressional action. ${ }^{84}$

While the majority described the telephone company's fears of liability as "unfounded," 85 it nevertheless ruled against compelling private assistance, and noted the dangers where such power is court-originated. The Second Circuit rationale included an explicit recognition of the possibility of overreaching by "overzealous" government agents which might violate privacy rights of third parties or those called upon to lend the government assistance. ${ }^{86}$ The court feared the possible ramifications of ordering unwilling private assistance in any circumstance without a clearly defined statute, ${ }^{87}$ adding that, unlike statutes such as Title III, judicial orders could not be drawn so as to limit possible intrusions by enforcement personnel. ${ }^{88}$ The majority was unwilling to find this statutory authorization in Congress' amendment of Title III to expressly provide the power to compel private assistance for wiretaps. While the Seventh Circuit had viewed the amendment as confirming congressional belief that the courts had inherent power to compel assistance, the Second Circuit thought it was "just as reasonable,

83. Id. at 961 .

84. Id.

85. Id. at 960 . Both the Second Circuit and the Seventh Circuit ignored the obvious fact that because pen registers are not included in Title III, the statutory immunity from suit provided therein for communication carriers is not necessarily applicable to pen registers. 18 U.S.C. $\$ 2520$ (1970) states that "good faith reliance on a court order . . . shall constitute a complete defense to any civil or criminal action brought under this chapter [Title III] or under any other law." (emphasis added). The unanswered question is whether the emphasized words (added by the 1970 amendments to Title III) are intended to include any interception of a wire or oral communication, within or outside Title III; if they do, then the telephone company's fears are unfounded, as the Second Circuit characterized them; if not, then the telephone company will be subject to potential liability. The Seventh Circuit's argument that, even though Title III's immunity provision is not applicable to pen registers the courts should provide a similar immunity by analogy, is nothing less than judicial lawmaking.

There is the additional problem of $\S 605$ of the Federal Communications Act; as discussed in notes $11 \& 22$ supra, it is not clear whether Title III was meant to totally preempt $\S 605$. If $\S$ 605 is still applicable to pen registers, the telephone company could be subject to civil or criminal penalties under it. Although there is an exception for interceptions conducted "on demand of lawful authority," its applicability would depend on whether the other circuits agree that a court order addressed to the telephone company is "lawful." See United States v. Illinois Bell Tel. Co., 531 F.2d 809, 814 (7th Cir. 1976); cf. Application of the United States (Second Cir.), 538 F.2d at 959 (holding that pen registers are not covered by $\S 605$ ).

In addition, unless Title III is held to totally preempt the field, there is the danger of liability under the Civil Rights Act, 42 U.S.C. $\$ 1983$ (1970), and under state constitutional and statutory provisions. See Reply Brief for Appellant at 6-7, United States v. Illinois Bell Tel. Co., 531 F.2d 809 (7th Cir. 1976); See also note 63 supra.

86. 538 F.2d at $962-63$.

87. Id. at 962 .

88. Id. 
if not more reasonable," to infer that Congress acted because it had a doubt that the courts possessed such inherent power, and that therefore it was "reasonable to conclude that similar [congressional] authorization should be required in connection with pen register orders . . . ." Until that time, it would not be possible for the government to obtain supplemental orders in the Second Circuit.

Judge Mansfield dissented from this part of the court's opinion. He saw no need to wait for congressional action, since in his view the district court had the authority to act under the All Writs Act. ${ }^{90} \mathrm{He}$ dismissed the majority's concern for potential privacy invasions resulting from compelled, unwilling assistance with a reminder not to worry about "imaginary and unlikely devils" 91 until they appear. He concluded that this was the paradigm case for the district court to exercise its discretionary power under the All Writs Act:

Because of the combination of clear necessity for Telephone Company assistance and the minimal burdens on that company, this is a case where application of such standards mandates assistance from the Telephone Company. Were the necessity lesser, or the burden greater, in some future case, a district court might not be justified in invoking its extraordinary powers. That is what the exercise of discretion is all about. ${ }^{92}$

The emphasized sentence taken from the dissent points up the curious feature of the majority opinion. The Second Circuit assumed that the district court had a discretionary power to compel the telephone company to assist the government, but the court held that the exercise of this power would be an automatic abuse of discretion. The exercise of discretion, as Judge Mansfield pointed out, calls for a case-by-case analysis; yet the majority opinion said that the exercise of this discretion would be an abuse of discretion in every case. The "Catch-22" operation of the majority's decision has the same effect as would a decision refusing to find the power to compel private assistance. It is impossible to determine why the court chose the route that it did, rather than the more straightforward one of refusing to find that power. ${ }^{93}$ By acting as it did, the Second Circuit was able to avoid determination of the troublesome issue of utilizing the notion of inherent judicial power or the All Writs Act in the face of Title III's

89. Id.

90. Id. at 963 (Mansfield, J., concurring and dissenting). Judge Mansfield disagreed with the majority's interpretation of the 1970 Amendment to Title III, noting that the legislative history was too "meager" to be helpful, id. at $964 \mathrm{n} .2$, and that it was improper to draw the inference that an express congressional grant of authority necessarily implies a prior lack of authority.

91. Id. at 966 .

92. Id. at 965 (emphasis added).

93. See notes 28-36 infra and accompanying text. 
comprehensive regulation of electronic surveillance. Although the decision is frustrating in the sense that it gives no final resolution to the question of power, it is satisfactory in the sense that it achieves a proper resultmandatory judicial abstention (at least in the Second Circuit) in favor of congressional action.

The most recent treatment of pen register usage by government agents and compelled telephone company installation assistance is that of the Eighth Circuit in Application of the United States for an Order Authorizing Installation and Use of a Pen Register..$^{94}$ Southwestern Bell argued that the use of the pen register is within the scope of Title III and that the district court, therefore, erred in ordering its assistance on the basis of a non-Title III application by the government. ${ }^{95}$ The Eighth Circuit had the benefit of both the Seventh and Second Circuit decisions. Adopting the Seventh Circuit view, the majority reiterated the definitional limitations of Title III, and held that pen registers are outside the scope of the Act. It concluded that use of the device depends entirely upon compliance with the fourth amendment, and that the district court had inherent authority to order the telephone company to assist the government with installation of the device. ${ }^{96} \mathrm{Mr}$. Justice Powell's partial dissent in United States v. Giordano was also cited to support the holding that the device can be used by the government and authorization for such use can be granted by the district court merely upon a showing of probable cause. ${ }^{97}$ In order to dispose of the troublesome Title III amendment history, the majority adopted the Seventh Circuit interpretation that Congress' action was "more in the nature of an overruling of the Ninth Circuit opinion." 98 This was a necessary preface, of course, to the court's ultimate holding that there is "inherent" power in the district courts to compel the assistance of the telephone company in the installation of the pen register. Interestingly, the Eighth Circuit treated the utilitarian argument advanced by the government-namely that without telephone company assistance the pen register order is worthless-as more important than its reading of the Title III amendment history! Finally, the majority paid a tribute to the Second Circuit dissent of Judge Mansfield with a parting line: "On the record before us we find no abuse of discretion by the district court in directing that the telephone company render assistance.",99 Obviously, the Eighth Circuit majority was unconvinced by the Second Circuit's

94. 546 F.2d 243 (8th Cir. 1976).

95. Id. at $245-46$.

96. Id. at 245 .

97. Id.

98. Id. at 246. See note 75 supra and accompanying text.

99. Id. at 247; see text accompanying note 93 supra for a discussion of the problems with the Second Circuit majority's "abuse of discretion" approach to court ordered telephone company assistance. 
strained approach to disallowing court-ordered telephone company assistance.

Although the appearance of the Eighth Circuit opinion in Application for an Order added another circuit to the list of those allowing the use of the pen register and the compelled unwilling assistance of the telephone companies, it also carried a forceful and well-reasoned dissent which contradicted many of the assumptions concerning inherent judicial power that are manifested in all three circuit opinions. Judge Lay first objected to the majority's adoption of the Seventh Circuit's interpretation of the Title III amendment history. Attacking the majority conclusion that this history evidenced Congress' original belief that the courts possessed inherent power sufficient to compel private assistance under Title III, the dissent points out that it is a "fundamental rule of statutory construction that Congress does not legislate needlessly." 100 On the issue of inherent power itself, the dissent strongly chided the majority for relegating the Seventh Circuit's reliance on the All Writs Act to a footnote, ${ }^{101}$ characterizing such relegation as a hesitance to fully adopt the Seventh Circuit rationale. ${ }^{102}$ The dissent next pointed out the facial inapplicability of Federal Rule of Criminal Procedure 41 to the seizure of intangibles and stressed that the cumulative history of Title III allowed only one reasonable inference- "that the only wire interceptions to be authorized are those subject to the safeguards of Title III." 103 Finally, the dissent pointed out the seriousness of any precedent which allows a court to compel private assistance to government agents without clearly defined authority. The central point of the lone dissenter is summed up in the last line of his opinion: "To me it is wrong that the judicial branch of government can thwart congressional intent and purpose by conjuring up some convenient, mystical authority through the pseudonym of 'inherent power.' "'104

A final, definitive determination of these questions may be forthcoming-the Supreme Court has granted the government's petition for certiorari to review the Second Circuit's decision. ${ }^{105}$

\section{The Issues in Perspective}

Both the government and the telephone company arguments are persuasive. Ironically, both of these arguments were used in support of the passage of Title III. ${ }^{106}$ The non-policy arguments supporting the courts'

100. 546 F.2d at 248 (Lay, J., dissenting).

101. Id. at 246 n.7.

102. Id. at 248 .

103. Id. at 249-50.

104. Id.

105. United States v. New York Tel. Co., 429 U.S. 1072 (1977), granting cert. to Application of the United States (Second Cir.).

106. See notes 5-6 supra and accompanying text. 
power to compel private assistance of telephone companies in the installation of the pen register must be examined in terms of the purported sources of such power-(1) analogy to Title III, (2) the All Writs Act, and (3) inherent judicial power. In addition, various policy factors must be considered to determine whether the use of such power sources is advisable.

\section{Title III Amendment Dispute}

A similar dispute over the courts' power to order private assistance in electronic surveillance arose in the context of Title III wiretaps. As originally enacted in 1968, Title III did not provide such power to the courts. In Application of the United States (Ninth Cir.), ${ }^{107}$ an early attempt by the government to force the telephone companies to assist in the installation of a wiretap was met with a refusal by the Ninth Circuit to find such authority within the Act or by implication. The Ninth Circuit held that the omission by Congress of such power had been purposeful, and the court directed the government to "address its plea to Congress." 108 Congress acted almost instantly, passing the 1970 Amendment to Title III to provide such power ${ }^{109}$ and to give the telephone companies broad immunity from suit for good faith reliance on court orders. ${ }^{110}$

Both the Second and Seventh Circuits noted that this Title III history is not directly applicable since pen registers do not fall within the ambit of Title III, but they nevertheless went on to draw different conclusions from it by analogy. The Seventh Circuit thought Congress was acting to overrule the Ninth Circuit's decision and reaffirm the fact that the courts have inherent power to compel private assistance. ${ }^{111}$ The Eighth Circuit adopted the Seventh Circuit view in its recent decision. ${ }^{112}$ The Second Circuit, on the other hand, found it equally reasonable that Congress acted "due to a doubt that the courts possessed inherent power to issue such orders . . . ."113 The legislative history of the 1970 Amendment is "meager," 114 and does not aid in choosing between the Seventh and Second Circuit interpretations. Since both are equally persuasive, the choice must be made on policy grounds. Title III was meant to be a comprehensive and stringent regulation of electronic surveillance. ${ }^{115}$ The courts, therefore, should not interfere in this area, but should leave it to Congress to make any changes in Title III's coverage that it believes is necessary. ${ }^{116}$ Congress has shown that it can act quickly when it sees the need. Given the importance of the interests

107. 427 F.2d 639 (9th Cir. 1970).

108. Id. at 644 .

109. 18 U.S.C. \& 2518(4) (1970).

110. Id. $\S 2520$ (1970).

111. 531 F.2d at 814.

112. 546 F.2d at 246.

113. 538 F.2d at 962.

114. Id. at 964 n.2 (Mansfield, J., concurring and dissenting).

115. See notes 2-6 supra and accompanying text.

116. See Application of the United States (Eighth Cir.), 546 F.2d at 250 (Lay, J., dissenting). 
involved, therefore, it is more in keeping with judicial moderation to choose the inference from the 1970 Amendments which would leave to Congress the necessity of legislating a further explicit grant of power if Congress believes it to be appropriate. The Second Circuit opinion and the Eighth Circuit dissent should be followed in this regard.

\section{All Writs Act}

The All Writs Act ${ }^{117}$ is a statutory authorization for various types of writs employed to supplement the courts' power in areas where jurisdiction already lies. ${ }^{118}$ It provides that a court "may issue" any writ "necessary or appropriate in aid of [its] respective [jurisdiction] and agreeable to the usages and principles of law." 119 The court's use of the power granted by the Act is entirely permissive; ${ }^{120}$ the Act can be seen as essentially a written version of the concept of inherent judicial power as it has been traditionally applied to effectuate prior orders threatened by non-compliance or obstruction by outside parties. ${ }^{21}$ If one were to concede the power of the district court to issue the original order authorizing the government's use of the pen register, the All Writs Act would provide statutory authority for the court, guided only by judicial discretion, ${ }^{122}$ to compel telephone company assistance. The Seventh Circuit so held, ${ }^{123}$ without any discussion of the discretionary aspect of the power. The Eighth Circuit has seemingly adopted the Seventh Circuit view. ${ }^{124}$ The Second Circuit noted that until United States v. Illinois Bell Telephone Co., the All Writs Act (or the notion of inherent judicial power) had never been construed to provide justification for the entry of this type order to effectuate a court's jurisdiction to order a search and seizure. ${ }^{125}$ The Second Circuit, assuming without deciding that the Seventh Circuit was correct in deciding that the All Writs Act gave the district court the discretionary power to compel telephone companies' assistance, nevertheless declared that the courts of appeals must determine whether the exercise of that power was proper or whether it was an abuse of

117. 28 U.S.C. $\S 1651$ (1970), quoted in note 32 supra.

118. See e.g. Brittingham v. United States Commissioner, 451 F.2d 315, 317 (5th Cir. 1971) (independent jurisdiction necessary to support a writ under 28 U.S.C. $\S 1651$ (1970)).

119. 28 U.S.C. $§ 1651$ (1970) (emphasis added).

120. Application of the United States (Second Cir.), 538 F.2d at 961.

121. Morrow v. District of Columbia, 417 F.2d 728 (D.C. Cir. 1969) (ancillary jurisdiction attaches to insure disposition in the main proceeding will not be frustrated); Faubus v. United States, 254 F.2d 797, 805 (8th Cir. 1958) (a preliminary injunction issued against the Governor and other state officials to prevent them from using the state National Guard to frustrate courtapproved high school integration plan); Mississippi Valley Barge Line Co. v. United States, 273 F. Supp. 6 (E.D. Mo. 1967), aff'd mem., 389 U.S. 579 (1968) (Where individuals not party to an original order acted to thwart such order, it was a proper exercise of discretion under the All Writs Act to issue a further injunction against them to effectuate the original order).

122. Application of the United States (Second Cir.), 538 F.2d at 961.

123. See notes 67-75 supra and accompanying text.

124. See notes $94-99$ supra and accompanying text.

125. 538 F.2d at 961; but see id. at 963-64 (Mansfield,J., concurring and dissenting). 
discretion. ${ }^{126}$ The court then turned the discretionary power into an absolute prohibition, holding that every exercise of that power would be an automatic abuse of discretion, absent congressional authorization. ${ }^{127}$

The Second Circuit's conclusion seems correct in light of the pervasive nature of Title III. The Supreme Court, commenting on the All Writs Act, announced this rule:

Unless appropriately confined by Congress, a federal court may avail itself of all auxiliary writs as aids in the performance of its duties, when the use of such historic aids is calculated in its sound judgment to achieve the ends of justice entrusted to it. ${ }^{128}$

Although Title III does not specifically deal with pen registers, it does pervasively cover the field of electronic surveillance. Congress thus has made a determination that the area of electronic surveillance is one properly dealt with through legislative rather than judicial action and therefore has "appropriately confined" the courts. Moreover, this pervasive congressional treatment should invoke application of the justiciability doctrine. The doctrine, which is a judicially created concept of avoidance employed when dealing with sensitive issues, ${ }^{129}$ has its roots in our system of coordinate branches of government. Its underlying premise is an awareness of the role of the federal judiciary vis-a-vis the other branches. A court applying this doctrine would examine the issue to determine whether there was the necessity to make "an initial policy determination of a kind clearly not for judicial discretion" 130 in order to reach a decision in the case at hand. It seems reasonably clear that the issue of whether the courts have the power to compel private party assistance is the sort of policy decision best left to Congress. ${ }^{131}$ Congress has seen fit, for whatever reasons, to amend Title III allowing for this type of extraordinary judicial order in the context of wiretaps. It is no less appropriate that Congress make any determinations as to the propriety of compelling private assistance in the installation of a pen register. The courts, then, should refrain from employing the All Writs Act to mandate telephone companies' assistance and await the decision of Congress.

\section{Inherent Judicial Power}

Inherent judicial power, a sort of unwritten All Writs Act, traditionally has been employed to effect remedies where none were explicitly provided

126. Id. at 961 .

127. See notes 81-84 supra and accompanying text.

128. Adams v. United States ex rel. McCann, 317 U.S. 269, 273 (1942) (emphasis added).

129. See, e.g., Baker v. Carr, 369 U.S. 186 (1962). The Supreme Court here offers its classic explanation of the factors involved in a determination that a particular case is non-justiciable because it involves a "political question."

130. Id. at 217.

131. See note 37 supra and accompanying text. 
by statute. ${ }^{132}$ Its limits are ill defined, expressed only in terms of what the courts may not do. ${ }^{133}$ The concerns of non-justiciability set forth above apply with equal force to the idea of employing inherent judicial power in order to compel telephone companies' assistance in the installation of a pen register. Although a court has the power to protect the integrity of its orders, it is arguably inappropriate to do so when the specific action required has been previously dealt with by Congress. Such action by Congress implies the necessity of making an initial policy decision properly committed to the legislative branch. This appears to be the reason for the Second Circuit's approach. Once it is decided that the district court has the power to authorize the use of a pen register, the power to compel the telephone companies' assistance follows logically from application of the All Writs Act or notions of inherent judicial power. Since, however, the exercise of that power is not mandatory but discretionary, and since the Second Circuit believed, as a policy preference, that the courts should wait for congressional authorization, it was able to reach the correct outcome by classifying any exercise of that discretion as an abuse of discretion.

\section{Policy Reasons Against Compelled Assistance}

Many courts may, nevertheless, be tempted to find and employ their discretionary power, ${ }^{134}$ under the All Writs Act or notions of inherent judicial power, to compel telephone company assistance in order to allow government use of the pen register in combating crime. Before they do, however, they should consider the ramifications of their actions. The primary policy reason not to compel assistance is the extraordinary nature of such a judicial act, and the precedent it will set for pressing unwilling citizens into a government service in the future. To compel a private party to assist in the apprehension of a known criminal, approved by the common law in the form of a posse comitatus, is one thing. ${ }^{135}$ Forced participation in

132. See, e.g., Bivens v. Six Unknown Named Narcotics Agents, 403 U.S. 388 (1971) (federal court can award damages for violation of fourth amendment rights without an independent jurisdictional basis); Reynolds v. Sims, 377 U.S. 533 (1964) (denial of constitutionally protected rights demands judicial protection); Soucie v. David, 448 F.2d 1067 (D.C. Cir. 1971); Burner v. Washington, 399 F. Supp. 44 (D.D.C. 1975) (court should intervene in governmental affairs when those affairs operate so as to fail to accord basic rights to persons affected thereby).

133. These limits are frequently set out in separation-of-powers terms. See, e.g., American Dredging Co. v. Local 25, Marine Division, Operating Engineers, 338 F.2d 837, 850 (3d Cir. 1964), cert. denied, 380 U.S. 935 (1964): "Courts have inherent power to construe legislation and to fashion remedies to effectuate the legislative design, but they do not have power to legislate, directly or indirectly, nor can they amend legislation to extend its clearly defined limits under shelter of power to fashion remedies."

134. An example is the action of the Eighth Circuit majority compelling telephone company assistance after the Second Circuit decision against such orders was handed down. See Application of the United States (Eighth Cir.), discussed in notes 94-104 and accompanying text.

135. BlaCK's LAW DictionaRY at 1324 (4th ed. 1968) defines posse comitatus as: 
governmental investigations of suspected criminal activity is quite another thing. Clearly, the courts are breaking new ground in this area, as evidenced by the novelty of the question when addressed by the Seventh Circuit in United States $v$. Illinois Bell Telephone Co. The potential ramifications of such an unqualified power to compel private assistance are quite serious:

No matter how carefully [the district courts might limit their decisions to the facts of the pen register context], there will no doubt be subsequent proceedings in which such a decision will be relied upon as precedent for expanding the assistance which can be compelled from private parties. ${ }^{136}$

The first extension of this practice might be to the mail cover, a process in many ways akin to the pen register. A mail cover is "a recordation of information contained on the outside of first class envelopes, such as the name and address of sender and addressee." 137 Heretofore, the Post Office has evidently cooperated in investigative efforts and has, upon request, voluntarily provided this information to various state and local law enforcement agencies. ${ }^{138}$ Now that an independent Board of Governors is running the postal service, ${ }^{139}$ they may realize the Service's potential liability for privacy invasions of citizens, as did the telephone companies' executives, and therefore refuse to voluntarily comply with government requests for surveillance. Can we not properly assume that, if the Seventh and Eighth Circuit decisions remain good law, a court order to the various local postmasters to carry on such mail covers would be forthcoming? The government might next persuade a court to order a private citizen to open his home against his will to a policeman for indefinite periods so that a suspect

The power or force of the county. The entire population of a county . . . which a sheriff may summon to his assistance in certain cases; as to aid him in keeping the peace, in pursuing and arresting felons, etc.;

See Application of the United States, 427 F.2d 639, 644 (9th Cir. 1970), where the court found this common law power of law enforcement officers inapplicable in the context of forced telephone company assistance in the installation of a wiretap. However, the government may have abandoned its analogy to the posse comitatus as a justification for a court's compelling telephone company assistance: "The government did not present its posse comitatus argument to this Court. It has apparently concluded that what the Ninth Circuit said about that motion in Application of United States was correct." Appplication of the United States (D. Mo.), 407 F. Supp. at 409 n.8.

136. Brief for Amicus Curiae American Civil Liberties Union of New Jersey at 18, In the Matter of an In-Progress Trace, No. 12, 269 (Supreme Court of New Jersey, filed October 4, 1976).

137. Cannady v. United States, 354 F.2d 849, 856 (8th Cir. 1966) (rejecting an invasion of privacy argument resulting from the use of a mail cover by the IRS).

138. See id.

139. Congress reorganized the Post Office Department under the new name of the United States Postal Service in 1970. The Service is now an "independent establishment of the executive branch," 39 U.S.C. $\$ 201$ (1970), run by a Board of Governors appointed by the President with the advice and consent of the Senate, 39 U.S.C. $\$ 202$ (1970), and possessing the power to sue and be sued in its official name, 39 U.S.C. $\$ 401(1)(1970)$. 
across the way could be viewed secretly through binoculars. The court would, indeed, be hard pressed to justify such an intrusion on privacy and freedom of choice; however, unless the court refuses to compel telephone companies' assistance in the installation of a pen register, it would be pushed to that extreme.

\section{CONCLUSION}

It is indeed unfortunate that Congress was not more specific in its treatment of the pen register in Title III, since the device is a useful law enforcement tool. While the inability of the government to use the device might hamper some investigative efforts, it is equally clear that invasions of an individual's privacy can result from improper use of the pen register. ${ }^{140}$ The assertion of a demanding need, albeit completely legitimate, cannot obviate the absolute necessity of preserving individual freedoms. Congress, then, must clarify the issue of investigative use of the pen register and the concomitant question of compelled private assistance in order to maintain our governmental integrity and societal security. Absent such congressional authorization, there is a strong argument that federal courts lack the power to authorize the use of the pen register by the executive branch. There are even stronger policy reasons why a court which nevertheless decides that it has such power, should refrain from using its discretionary power to compel telephone company assistance. The courts must refrain from taking that dangerous "first step down a long road" referred to by the Second Circuit.

140. There is not only the limited intrusion caused by the use of the pen register itself, but also the danger that it would be secretly converted into a wiretap. See note 45 sipra and accompanying text. 